\title{
Isolation and identification of guaiacol-producing Alicyclobacillus fastidiosus strains from orchards in Poland
}

\author{
Marzena Połaska, Agnieszka Dekowska and Barbara Sokołowska ${ }^{\square}$ \\ Department of Microbiology, Prof. Wacław Dąbrowski Institute of Agricultural and Food Biotechnology - State Research Institute, Warsaw, Poland
}

\begin{abstract}
The genus Alicyclobacillus comprises a group of Grampositive, endospore-forming, and thermo-acidophilic bacteria. Some of the Alicyclobacillus species are categorized as spoilage bacteria due to their ability to produce off-flavor compounds (e.g. guaiacol and halophenols) that adversely affect the taste and aroma of beverages. In our study, Alicyclobacillus species isolated from Polish orchard soils and fruits were subjected to 16S rDNA sequencing and $r p o B$ gene RFLP analysis. The results showed that the isolated strains belong to the species $A$. acidoterrestris and $A$. fastidiosus. Additionally, a fragment of the $v d c$ operon, which is responsible for guaiacol production, was amplified and subjected to RFLP analysis. The resulting RFLP patterns allowed classifying five strains as $A$. acidoterrestris type II, while the patterns of another three strains showed no similarity to the patterns of any reference strains used for comparison. The reference strain $A$. fastidiosus DSM 17978 did not give any PCR product in this reaction, nor showed guaiacol production. All the three isolated strains of $A$. fastidiosus were subjected to a series of tests, including determination of the biochemical profile using API $50 \mathrm{CH}$ tests and determination of the ability to produce guaiacol at $20^{\circ} \mathrm{C}$, $25^{\circ} \mathrm{C}$, and $45^{\circ} \mathrm{C}$. All $A$. fastidiosus strains exhibited similar morphological and biochemical properties as the strain described in the literature. However, our strains, unlike the strain described previously, were able to produce guaiacol at all tested temperatures, and could therefore be included in the group of spoilage species. To date, this study is the first to report the isolation of $A$. fastidiosus from Poland and is the second such report in the world.
\end{abstract}

Keywords: Alicyclobacillus fastidiosus, Alicyclobacillus acidoterrestris, thermo-acidophilic bacteria, guaiacol; RFLP, vdc operon, rpoB gene

Received: 12 December, 2020; revised: 17 February, 2021; accepted: 18 February, 2021; available on-line: 10 May, 2021

$\square$ e-mail: barbara.sokolowska@ibprs.pl

Accession numbers: KY088041, KY088042, KY088043, KY088044, KY088045, KY088046, KY088047, MW332524

Abbreviations: API, analytical profile index; ATCC, American Type Culture Collection; BLAST, Basic Local Alignment Search Tool; CIM, Culture Collection of Industrial Microorganisms; DSMZ, German Collection of Microorganisms and Cell Cultures GmbH; IFU, International Federation of Fruit Juice Producers; PCR, polymerase chain reaction; RFLP, Restriction fragment length polymorphism; WGS, Whole Genome Sequencing

\section{INTRODUCTION}

The genus Alicyclobacillus comprises Gram-positive, thermo-acidophilic, nonpathogenic, and spore-forming bacteria. Alicyclobacillus species possess unique fatty acids (cyclohexane or cycloheptane) in their cell membrane
(Deinhard et al., 1987a; Deinhard et al., 1987b). These thermo-acidophilic bacteria were first isolated from different hot springs in Japan (Uchino \& Doi 1967). Alicyclobacillus species are also found in soil which acts as the main reservoir of these bacteria (Goto et al., 2008; Groenewald et al., 2008; Wang et al., 2010). In addition, the soil is an important source of fruit contamination by Alicyclobacillus spores, which are transmitted by wind or during the harvesting period. For several years, the fruit juice industry has been affected by the problem of deterioration of fruits by Alicyclobacillus species (Sokołowska et al., 2020).

The metabolic products of these bacteria, which include halophenols (2,6-dibromophenol and 2,6-dichlorophenol) and guaiacol, are responsible for the formation of unusual medical, phenolic off-flavor and for the adverse changes noted in the taste and aroma of the fruit juice products (Pettipher et al., 1997; Orr et al., 2000). Furthermore, Alicyclobacillus spores are heat-resistant and can therefore survive pasteurization. The thermal and acid resistance of Alicyclobacillus is the result of the unique composition of fatty acids in the cell membrane of these organisms. These fatty acids contribute to increased packing of lipids in the membrane core and the stabilization of the membrane structure of the bacteria, which in turn allow them to tolerate high temperatures and highly acidic conditions (Kannenberg et al., 1984; Chang et al., 2004; Karavaiko et al., 2005; Ciuffreda et al., 2015).

Thus far, 26 species of Alicyclobacillus have been identified. Eight of these $-A$. acidiphilus, $A$. acidoterrestris, A. dancy, A. herbarius, A. cyclobeptanicus, A. pomorum, A. contaminans, and some strains of $A$. hesperidum - were reported to have the ability to produce guaiacol (Deinhard et al., 1987a; Deinhard et al., 1987b; Wisotzkey et al., 1992; Albuquerque et al., 2000; Goto et al., 2002; Matsubara et al., 2002; Goto et al., 2003; Goto et al., 2007; Jiang et al., 2008; Guo et al., 2009; Nakanano et al., 2015). Among all the Alicyclobacillus species, A. acidoterrestris was found to be the most prevalent cause of pasteurized beverages spoilage (Durak et al., 2010; Sokołowska et al., 2016).

$16 \mathrm{~S}$ rDNA gene is an essential tool in taxonomy, especially considering the large and still-growing database of $16 \mathrm{~S}$ rDNA sequences, derived from diverse microorganisms. However, it does not always allow distinguishing closely related species; in addition, most microorganisms have several non-identical copies of this gene in their genome, which makes PCR-RFLP analysis difficult. Thus, we decided to include the $r p o B$ gene in our taxonomy studies. $\mathrm{R} p o B$ encodes the $\beta$-subunit of bacterial RNA polymerase. This is a housekeeping gene that occurs in the genome in one copy, is widely used in taxonomy, 
and has already been used to identify and differentiate Alicyclobacillus strains (Dekowska et al., 2018).

To date, there have been no reports on the guaiacolproducing ability of $A$. fastidiosus. In $A$. acidoterrestris, guaiacol production is determined by the $v d c$ operon consisting of three genes: $v d c B, v d c C$, and $v d c D$ (Matsubara et al., 2003). The presence of this operon was confirmed in $A$. acidoterrestris, $A$. acidophilus, and $A$. herbarius. The operon sequence has been proven to be a useful marker in differentiating Alicyclobacillus strains that are capable of producing guaiacol (Dekowska et al., 2018).

In this study, we aimed to confirm the presence of Alicyclobacillus bacteria in Polish fruit orchards and characterize the three atypical $A$. fastidiosus strains that were isolated for the first time from the orchards in the Mazovia region of Poland.

\section{MATERIALS AND METHODS}

\section{Bacterial strains}

The bacteria tested in the study were isolated from the samples taken from the top layer of soil and from the apple and pear fruits that were hand-collected from various orchards in the Mazovia region of Poland. All isolated strains were deposited in the Culture Collection of Industrial Microorganisms (CIM) at the Institute of Agricultural and Food Biotechnology (collection number in World Federation for Culture Collections WDCMIAFB 212).

The following reference strains were used in the study: A. acidoterrestris ATCC 49025, A. acidoterrestris DSM 2498, A. acidiphilus DSM 14558, $A$. herbarius DSM 13609, $A$. hesperidum DSM 12489, $A$. acidocaldarius DSM 446, and $A$. fastidiosus DSM 17978. These strains were obtained from the American Type Culture Collection and Leibnitz Institute DSMZ - German Collection of Microorganisms and Cell Cultures $\mathrm{GmbH}$.

\section{Alicyclobacillus species isolation and differentiation from other thermo-acidophilic bacterial species}

The taint-producing Alicyclobacillus species was isolated using the International Federation of Fruit Juice Producers (IFU) Method No. 12 (IFU Method No. 12, 2004/2007). Twenty soil samples and 20 fruit samples were taken manually from the five orchards in the Mazovia region for the study. The fruit or soil samples $(10 \mathrm{~g})$ were mixed with $90 \mathrm{ml}$ of BAT broth (Merck, Darmstadt, Germany) and were heat-treated at $80^{\circ} \mathrm{C}$ for $10 \mathrm{~min}$. This high-temperature treatment eliminated other vegetative microbial contaminants and induced the germination of spores. Following the heat treatment, the samples were incubated for 5 days at $45^{\circ} \mathrm{C}$. Then, a loop of suspension was transferred onto BAT agar ( $\mathrm{pH} 4.0 \pm 0.1$ ) (Merck), and the plates were incubated for 3 days at $45^{\circ} \mathrm{C}$. The cell morphology of all the isolated strains was studied by Gram staining and observation under an Olympus CX40 microscope (oil immersion, $\times 1500$ magnification). Then, single colonies were spread-plated onto Plate Count Agar (PCA, pH 7.0 \pm 0.2 ) (Merck) to exclude the presence of Bacillus. In addition, the colonies assumed to be belonging to the genus Alicyclobacillus were spread-plated onto BAT agar and incubated at $65^{\circ} \mathrm{C}$ for 3 days. The presumptive strains were confirmed as taint-producing Alicyclobacillus if they could not grow on the BAT agar medium at a temperature of $65^{\circ} \mathrm{C}$ (Goto, 2007; IFU Method No. 12, 2004/2007).
According to the IFU Method No. 12, the isolated strains that potentially belonged to the Alicyclobacillus family were tested for the ability to produce guaiacol at $45^{\circ} \mathrm{C}$ (Niwa \& Kuriyama, 2013). A 24-h plate culture of Alicyclobacillus species capable of causing spoilage was added to $1 \mathrm{ml} \mathrm{BAT}$ broth with vanillic acid $(100 \mathrm{mg} / \mathrm{l})$ and incubated for $3-4 \mathrm{~h}$ at $45^{\circ} \mathrm{C}$. After incubation, guaiacol was detected through its oxidation by peroxidase (50 $\mu \mathrm{l}$ of $0.01 \%$ peroxidase in $500 \mu \mathrm{l}$ of phosphate buffer $(\mathrm{pH} 6.0 \pm 0.1)$ ), in the presence of hydrogen peroxide $(50$ $\mu \mathrm{l}$ of $\left.0.5 \% \mathrm{H}_{2} \mathrm{O}_{2}\right)$. The reaction resulted in the formation of brown-colored 3,3'-dimethoxy-4,4'-biphenoquinolone.

An additional confirmatory test was performed for differentiating $A$. acidoterrestris from other Alicyclobacillus species, according to the method described by Baumgart's team (Baumgart et al., 2003). The presumptive $A$. acidoterrestris colonies isolated from the BAT agar plates were streaked onto erythritol agar $(1.0 \mathrm{~g}$ yeast extract, $10.0 \mathrm{~g}$ erythritol, $0.25 \mathrm{~g} \mathrm{CaCl}_{2} \cdot 2 \mathrm{H}_{2} \mathrm{O}, 0.5 \mathrm{~g} \mathrm{MgSO}_{4} \cdot 7 \mathrm{H}_{2} \mathrm{O}, 0.2 \mathrm{~g}$ $\left(\mathrm{NH}_{4}\right)_{2} \mathrm{SO}_{4}, 3.0 \mathrm{~g} \mathrm{K \textrm {KH } _ { 2 }} \mathrm{PO}_{4}, 0.015 \mathrm{~g}$ bromophenol blue, $18.0 \mathrm{~g}$ agar, $1000 \mathrm{ml}$ deionized water, and $1 \mathrm{ml}$ solution of trace minerals consisting of $0.066 \mathrm{~g} \mathrm{CaCl}_{2} \cdot 2 \mathrm{H}_{2} \mathrm{O}, 0.018$ g $\mathrm{ZnSO}_{4} \cdot 7 \mathrm{H}_{2} \mathrm{O}, 0.016 \mathrm{~g} \mathrm{CuSO}, 0.015 \mathrm{~g} \mathrm{MnSO}_{4} \cdot \mathrm{H}_{2} \mathrm{O}$, $0.018 \mathrm{~g} \mathrm{CoCl} \cdot 6 \mathrm{H}_{2} \mathrm{O}, 0.01 \mathrm{~g} \mathrm{H}_{3} \mathrm{BO}_{3}, 0.03 \mathrm{~g} \mathrm{Na}_{2} \mathrm{MoO}_{4}$, and $100 \mathrm{ml}$ deionized water) and were incubated at $45^{\circ} \mathrm{C}$ and $65^{\circ} \mathrm{C}$ for 3 days.

The growth of $A$. acidoterrestris was confirmed if the bacterial colony showed a green color, accompanied by a change in the color of the medium from blue to yellow (green color was observed during incubation at $45^{\circ} \mathrm{C}$ ). Furthermore, a lack of growth was observed at $65^{\circ} \mathrm{C}$ for this species. Other Alicyclobacillus species (e.g. A. acidocaldarius) showed blue colonies on erythritol agar due to the lack of acid formation from erythritol at both $45^{\circ} \mathrm{C}$ and $65^{\circ} \mathrm{C}$.

\section{Identification of bacterial isolates via 16S rDNA gene sequence analysis}

The bacterial isolates that were assumed to be belonging to the Alicyclobacillus genus were subjected to $16 \mathrm{~S}$ rDNA gene sequence analysis. DNA was isolated from the bacterial cells using Genomic DNA Purification Kit (EUR ${ }_{\mathrm{x}}$, Gdańsk, Poland) according to the manufacturer's instruction. The fragment of the $16 \mathrm{~S}$ rDNA gene (1500 bp) was amplified and sequenced using primers fD1 (5'-AGAGTT'TGATCCTGGCTCAG) and Alicyc16 srev (5'-ACGGCTACCTTGT'TACGACT). The composition of the PCR mixture was as follows: $5 \mathrm{ng}$ of template DNA, $50 \mathrm{pM}$ of each of the primers, $25 \mu \mathrm{l}$ of DreamTaq ${ }^{\mathrm{TM}}$, and Green PCR Master Mix (Thermo Scientific, Wallham, USA) with water added to obtain a final volume of $50 \mu \mathrm{l}$. PCR was performed under the following conditions: initial denaturation at $94^{\circ} \mathrm{C}$ for 2 min, followed by 40 cycles of denaturation at $94^{\circ} \mathrm{C}$ for $30 \mathrm{~s}$, annealing at $51^{\circ} \mathrm{C}$ for $35 \mathrm{~s}$, elongation at $72^{\circ} \mathrm{C}$ for $1 \mathrm{~min}$ and $40 \mathrm{~s}$, and the final elongation at $72^{\circ} \mathrm{C}$ for 2 min. The obtained sequences were assembled using Serial Cloner (Serial Basic) and compared to the GenBank database using BLAST. DNA sequences obtained during this study were deposited in GenBank, and their accession numbers are given in Table 1.

\section{RFLP analysis of $r p o B$ gene fragment and vdc operon fragment}

The RFLP analysis was carried out as described by Dekowska's group (Dekowska et al., 2018). Briefly, the rpoB gene fragment (1735 bp) was amplified using Gru3Gru6 primers, the sequences of which were as follows: 
Table 1. Alicyclobacillus strains isolated from the orchards in the Mazovia region of Poland.

\begin{tabular}{|c|c|c|c|c|}
\hline Strains & Source of isolation & Species & CIM number & GenBank accession number \\
\hline Strain 1 & Soil from apple orchard & Alicyclobacillus acidoterrestris & KKP 3194 & KY088041 \\
\hline Strain 2 & Soil from apple orchard & Alicyclobacillus acidoterrestris & KKP 3195 & KY088042 \\
\hline Strain 3 & Apples & Alicyclobacillus acidoterrestris & KKP 3347 & KY088043 \\
\hline Strain 4 & Soil from apple orchard & Alicyclobacillus acidoterrestris & KKP 3348 & KY088047 \\
\hline Strain 5 & Apples & Alicyclobacillus acidoterrestris & KKP 3349 & MW332524 \\
\hline Strain $\mathrm{f} 1$ & Soil from pear orchard & Alicyclobacillus fastidiosus & KKP 3000 & KY088044 \\
\hline Strain $\mathrm{f} 2$ & Pears & Alicyclobacillus fastidiosus & KKP 3001 & KY088045 \\
\hline Strain $\mathrm{f3}$ & Soil from pear orchard & Alicyclobacillus fastidiosus & KKP 3002 & KY088046 \\
\hline
\end{tabular}

Gru3: 5'-CGYGACGTDCACTAYTCBCACTA,

Gru4: 5'-GCCCANACYTCCATCTCRCCRAA,

Gru5: 5'-CGCGACGTACACTATTCGCACTA, and

Gru6: 5'-GCCCAAACCTCCATCTCACCAAA.

The primers Gru5 and Gru6 were nondegenerated versions of the primers Gru3 and Gru4, respectively. The nondegenerated primers were used for amplifying the $A$. acidoterrestris samples, while the degenerated ones were used for amplifying other samples. All the primers were designed based on the comparison of $r p o B$ sequences isolated from several Alicyclobacillus species, $\mathrm{Ba}$ cillus subtilis, and Geobacillus stearothermophilus published in GenBank.

The composition of the PCR mixture was as follows: $30 \mathrm{ng}$ of template DNA, $40 \mathrm{pM}$ of each of the primers, $25 \mu \mathrm{l}$ of DreamTaq ${ }^{\mathrm{TM}}$, and Green PCR Master Mix (Thermo Scientific) with water added to obtain the final volume of $50 \mu \mathrm{l}$. PCR was performed under the following conditions: initial denaturation at $94^{\circ} \mathrm{C}$ for $2 \mathrm{~min}$, followed by 40 cycles of denaturation at $94^{\circ} \mathrm{C}$ for $30 \mathrm{~s}$, annealing at $57^{\circ} \mathrm{C}$ (for the Gru5 and Gru6 primers) or at $59^{\circ} \mathrm{C}$ (for the Gru3 and Gru4 primers) for 35 s, elongation at $72^{\circ} \mathrm{C}$ for $1 \mathrm{~min} 45 \mathrm{~s}$, and the final elongation at $72^{\circ} \mathrm{C}$ for $2 \mathrm{~min}$.

The $v d c$ operon fragment (1810 bp) was amplified and sequenced using primers Vdc1fr (5'-AACGACGCAGGTGTGGAAAC) and Bur6 (5'-GTSGCRTCGAGAATCATCTTGTG). These primers were designed based on the raw genome sequences of $A$. acidoterrestris ATCC 49025 (Shemesh et al., 2013) (GenBank accession number AURB01000113.1) and A. herbarius DSM 13609 (GenBank accession number AUMH01000032.1) and the sequence published by Matsubara (2003) (JP 2003000259-A12, 07-Jan-2003; GenBank accession number BD187778.1).

The PCR mixture contained 25 ng of template DNA, $15 \mathrm{pM}$ of each of the primers, $25 \mu \mathrm{l}$ of DreamTaq ${ }^{\mathrm{TM}}$, and Green PCR Master Mix (Thermo Scientific) with water added to obtain the final volume of $50 \mu \mathrm{l}$. PCR was performed under the following conditions: initial denaturation at $94^{\circ} \mathrm{C}$ for $2 \mathrm{~min}$, followed by 30 cycles of denaturation at $94^{\circ} \mathrm{C}$ for $30 \mathrm{~s}$, annealing at $56^{\circ} \mathrm{C}$ for 35 $\mathrm{s}$, elongation at $72^{\circ} \mathrm{C}$ for $1 \mathrm{~min} 50 \mathrm{~s}$, and the final elongation at $72^{\circ} \mathrm{C}$ for $2 \mathrm{~min}$.

The PCR-RFLP assay was performed according to the following procedure. First, 8-12 $\mu \mathrm{l}$ of the PCR products was digested with endonuclease HphI (Thermo Scientif- ic) in a volume of $20 \mu \mathrm{l}$. Following incubation at $37^{\circ} \mathrm{C}$ for $1-2 \mathrm{~h}$ and inactivation of the enzyme $\left(10 \mathrm{~min}, 80^{\circ} \mathrm{C}\right)$, the samples were analyzed on a $2.5-3.0 \%$ agarose gel.

\section{Growth profile}

For determining the growth temperature range of the isolates, $20 \mu \mathrm{l}$ of 18 -h bacterial culture was added to 2 $\mathrm{ml}$ of BAT broth and incubated at different temperatures: $20^{\circ} \mathrm{C}, 25^{\circ} \mathrm{C}, 30^{\circ} \mathrm{C}, 37^{\circ} \mathrm{C}, 40^{\circ} \mathrm{C}, 45^{\circ} \mathrm{C}, 50^{\circ} \mathrm{C}, 55^{\circ} \mathrm{C}$, $60^{\circ} \mathrm{C}$, and $65^{\circ} \mathrm{C}$. The optical density of the bacterial suspension was measured after $24 \mathrm{~h}, 48 \mathrm{~h}$, and $72 \mathrm{~h}$ of incubation (McFarland Densitometer DEN-1B, Biosan, Riga, Latvia).

To determine the growth $\mathrm{pH}$ range of $A$. fastidiosus, the $\mathrm{pH}$ of the BAT broth was adjusted by adding $1 \mathrm{M}$ sulfuric acid to achieve the following values: $2.5,3.0,3.5$, $4.0,4.5,5.0$, and 5.5. The medium was inoculated with 18-h bacterial culture and incubated at an optimal temperature of $40^{\circ} \mathrm{C}$ for $24 \mathrm{~h}, 48 \mathrm{~h}$, and $72 \mathrm{~h}$. Following each incubation period, the optical density of the bacterial suspension was measured.

\section{Assessment of the guaiacol-producing ability of A. fastidiosus isolates at three different temperatures}

The ability to produce guaiacol was tested using the peroxidase method (Niwa \& Kuriyama, 2013). The f1, $\mathrm{f} 2$, and $\mathrm{f} 3$ strains of $A$. fastidiosus were cultivated on BAT agar plates for $72 \mathrm{~h}$ at three different temperatures: $20^{\circ} \mathrm{C}, 25^{\circ} \mathrm{C}$, and $45^{\circ} \mathrm{C}$. Briefly, the BAT broth medium supplemented with vanillic acid $(100 \mathrm{mg} / \mathrm{l})$ was inoculated with a loop of harvested cells of $A$. fastidiosus. The medium was incubated for $7 \mathrm{~h}$ at $20^{\circ} \mathrm{C}, 25^{\circ} \mathrm{C}$, and $45^{\circ} \mathrm{C}$. If the guaiacol was present, the color change of the medium containing vanillic acid and the bacterial strain was observed after adding an appropriate amount of phosphate buffer, peroxidase, and hydrogen peroxide.

\section{Biochemical profile}

The ability of the $A$. fastidiosus isolates to produce acid from various carbohydrates and their derivates (heterosides, polyalcohols, uronic acids) was tested at the optimum growth temperature $-40^{\circ} \mathrm{C}$. The API $50 \mathrm{CH}$ (bioMerieux. Marcy l'Etoil, France) test kits supplemented with medium $\left(0.5 \mathrm{~g}\right.$ yeast extract, $0.25 \mathrm{~g} \mathrm{CaCl} \cdot 2 \mathrm{H}_{2} \mathrm{O}$, $0.5 \mathrm{~g} \mathrm{MgSO}_{4} \cdot 7 \mathrm{H}_{2} \mathrm{O}, 0.2 \mathrm{~g}\left(\mathrm{NH}_{4}\right)_{2} \mathrm{SO}_{4}, 3.0 \mathrm{~g} \mathrm{KH}_{2} \mathrm{PO}_{4}, 1$ 
$\mathrm{ml} 0.75 \%$ bromophenol blue solution as an indicator of acidification, $1000 \mathrm{ml}$ deionized water, and $1 \mathrm{ml}$ solution of trace minerals consisting of $0.066 \mathrm{~g} \mathrm{CaCl}_{2} \cdot 2 \mathrm{H}_{2} \mathrm{O}, 0.018$ g $\mathrm{ZnSO}_{4} \cdot 7 \mathrm{H}_{2} \mathrm{O}, 0.016 \mathrm{~g} \mathrm{CuSO}_{4}, 0.015 \mathrm{~g} \mathrm{MnSO}_{4} \cdot \mathrm{H}_{2} \mathrm{O}$, $0.018 \mathrm{~g} \mathrm{CoCl} \cdot 6 \mathrm{H}_{2} \mathrm{O}, 0.01 \mathrm{~g} \mathrm{H}_{3} \mathrm{BO}_{3}, 0.03 \mathrm{~g} \mathrm{Na}_{2} \mathrm{MoO}_{4}$, and $100 \mathrm{ml}$ deionized water) were used for this analysis (Deinhard et al., 1987a; Deinhard et al., 1987b).

\section{RESULTS AND DISCUSSION}

\section{Identification of Alicyclobacillus bacteria based on culture-dependent methods}

The samples of the top layer of soil as well as the apple and pear fruits collected from the orchards in the Mazovia region, one of the biggest fruit-producing regions of Poland, were screened for the presence of taintproducing Alicyclobacillus. Eight isolated bacterial strains were characterized as Gram-positive, spore-forming bacilli and were found to be able to grow on BAT agar at $45^{\circ} \mathrm{C}$, whereas at the same temperature they could not grow on PCA. Based on these observations, they were classified as the members of Alicyclobacillus genus. Furthermore, these isolates could not grow at $65^{\circ} \mathrm{C}$, which is a characteristic of presumptive taint-producing Alicyclobacillus species (IFU Method No. 12, 2004/2007). All the eight isolated strains exhibited the ability to produce guaiacol at $45^{\circ} \mathrm{C}$.

According to Baumgart and others (Baumgart et al., 2003), the species $A$. acidoterrestris has the ability to utilize erythritol as a carbon source for acid formation, which is indicated by the growth of yellow-green colonies on erythritol agar with bromophenol blue. In the present study, five acidophilic strains - strain 1, strain 2, strain 3 , strain 4, and strain 5 - isolated from apples and soil samples collected from apple orchard were able to grow on erythritol agar and formed yellow-green colonies, whereas three acidophilic strains - strain f1, strain f2, and strain $\mathrm{f} 3$ - isolated from pears and soil samples collected from pear orchard formed blue colonies on this medium. Taking these results into account, we can assume that strains $1-5$ belong to the species $A$. acidoterrestris, whereas strains $\mathrm{f} 1, \mathrm{f} 2$, and $\mathrm{f} 3$ do not belong to this species although they showed guaiacol-producing ability.

\section{Sequence analysis and PCR-RFLP}

The 16S rDNA sequence analysis indicated that strains f1, f2, and f3 probably belong to the species A. fastidiosus. The $16 \mathrm{~S} \mathrm{rDNA}$ sequences of these isolates showed the highest identity $(>99 \%)$ to those of the strain A. fastidiosus DSM 17978 (GenBank accession number AB264021) and two other $A$. fastidiosus strains (NR_041471 and NR_114208). On the other hand, strains 1-5 were identified as $A$. acidoterrestris (>99\% identity to $A$. acidoterrestris).

RFLP analysis was performed for the $r p o B$ gene fragment of all the analyzed Alicyclobacillus strains, and their patterns were compared to those of the following reference strains: $A$. acidoterrestris DSM 2498, $A$. acidoterrestris ATCC 49025, A. acidiphilus DSM 14558, A. herbarius DSM 13609, A. hesperidum DSM 12489, A. acidocaldarius DSM 446 (Fig. 1a), and A. fastidiosus DSM 17978 (Fig. 1b). The RFLP patterns of strains $\mathrm{f1}$ and $\mathrm{f3}$ were identical to that of $A$. fastidiosus DSM 17978, while the pattern of strain $\mathrm{f} 2$ was not identical but similar to that of the mentioned strain. Based on the comparison of the RFLP patterns of all $A$. acidoterrestris strains and isolates $\mathrm{f} 1, \mathrm{f} 2$, and $\mathrm{f} 3$, we excluded the possibility that strains $\mathrm{f} 1$, $\mathrm{f} 2$, and $\mathrm{f} 3$ belong to $A$. acidoterrestris species, whereas the rest of the analyzed strains were found to show identical patterns as A. acidoterrestris type II ATCC 49025 (Fig. 1a and $1 \mathrm{~b}$ ). So far, two types (type I and type II) of $A$. acidoterrestris strains have been reported (Durak et al., 2010, Osopale et al., 2016, Dekowska et al., 2018). In this study, we observed only type II $A$. acidoterrestris. Dekowska's team (Dekowska et al., 2018) analyzed 60 A. acidoterrestris species isolated from Polish fruits and fruit products and showed that the distribution of these species was quite even with 27 belonging to type I and 33 to type II.

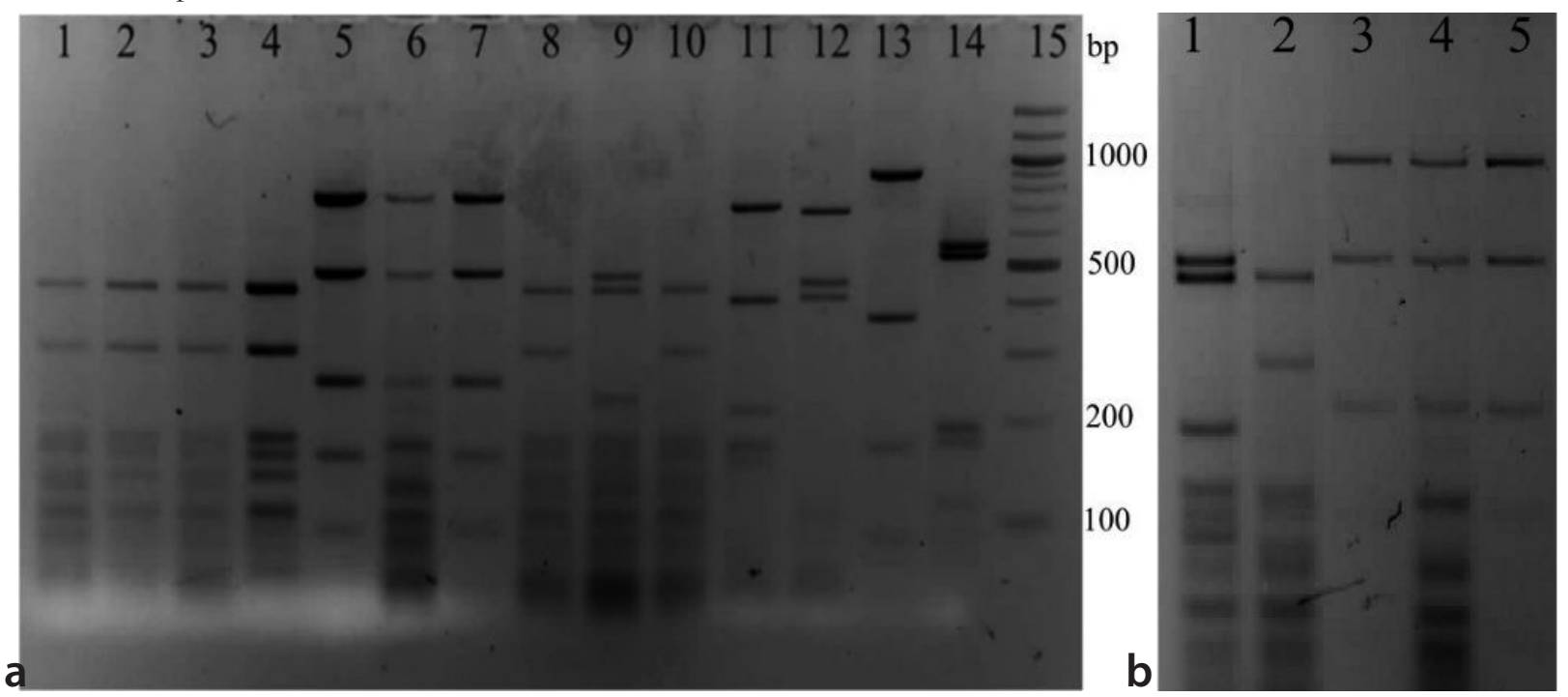

Figure 1a. RFLP patterns of the $r p o B$ gene isolated from the analyzed strains.

Lane 1: A. acidoterrestris strain 1, lane 2: A. acidoterrestris strain 2, lane 3: A. acidoterrestris strain 3, lane 4: A. acidoterrestris strain 4, lane 5: A. fastidiosus strain $\mathrm{f} 1$, lane 6: A. fastidiosus strain $\mathrm{f} 2$, lane 7: A. fastidiosus strain $\mathrm{f} 3$, lane 8: A. acidoterrestris strain 5, lane 9: A. acidoterrestris type I DSM 2498, lane 10: A. acidoterrestris type II ATCC 49025, lane 11: A. acidiphilus DSM 14558, lane 12: A. hesperidum DSM 12489, lane 13: A. herbarius DSM 13609, lane 14: A. acidocaldarius DSM 446, lane15: DNA molecular weight marker $\lambda / A$ vall.

Figure $1 \mathrm{~b}$. RFLP patterns of the $r p \circ B$ gene isolated from the analyzed strains.

Lane 1: A. acidoterrestris type I DSM 2498, lane 2: A. acidoterrestris type II ATCC 49025, lane 3: A. fastidiosus DSM 17978, lane 4: A. fastidiosus strain $\mathrm{f} 2$, and lane 5: A. fastidiosus strain $\mathrm{f} 3$. 


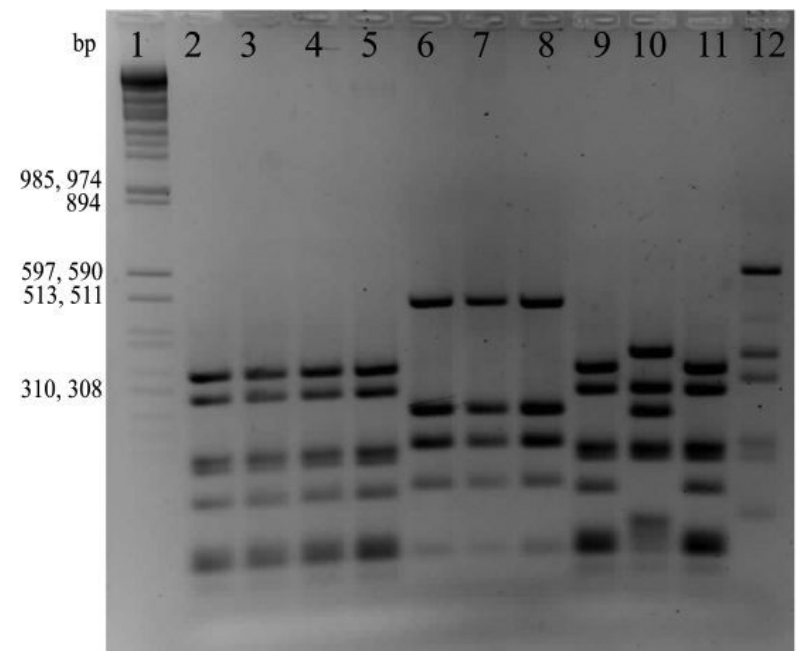

Figure 2. RFLP analysis of the $v d c$ operon fragment isolated from the analyzed strains.

Lane 1: DNA molecular weight marker $\lambda /$ Avall, lane 2: A. acidoterrestris strain 1, lane 3: $A$. acidoterrestris strain 2, lane 4: $A$. acidoterrestris strain 3, lane 5: $A$. acidoterrestris strain 4, lane 6: $A$. fastidiosus strain $\mathrm{f} 1$, lane 7: $A$. fastidiosus strain $\mathrm{f} 2$, lane 8 : $A$. fastidiosus strain $\mathrm{f3}$, lane 9: $A$. acidoterrestris strain 5, lane 10: $A$. acidoterrestris type I DSM 2498, lane 11: A. acidoterrestris type II ATCC 49025, and lane 12: A. acidiphilus DSM 14558.

The performed PCR assay targeting the $v d c$ operon fragment resulted in a product of about $1800 \mathrm{bp}$ for all the tested strains, regardless of whether they were classified as $A$. acidoterrestris or $A$. fastidiosus. A band of identical size was obtained for both reference strains of $A$. acidoterrestris, but not for the reference strain $A$. fastidiosus DSM 17987. The strain A. fastidiosus DSM 17987 probably carries a defective version of the operon as Wang and coworkers (Wang et al., 2021) obtained a PCR product for this strain using primers designed for $v d c C$ gene, whereas they did not observe guaiacol production. This suggests that whole-genome sequencing or further study on this particular region is required to shed more light on this issue.

The RFLP analysis of the $v d c$ operon fragment showed that the patterns obtained for the environmental samples classified as $A$. acidoterrestris were identical to those of $A$. acidoterrestris type II ATCC 49025, while the patterns obtained for the environmental samples classified as $A$. fastidiosus were identical to each other and showed no similarity to the patterns of any reference strain. The strain $A$. fastidiosus DSM 17978 produced no band in the PCR assay and, therefore, it was excluded from the RFLP analysis (Fig. 2).

Sequences of the analyzed $v d c$ fragment (GenBank accession number MH938036) were found to be identical to those of all three strains of $A$. fastidiosus isolated in this study, and they showed $80 \%, 76 \%$, and $71 \%$ identity to the sequences of $A$. acidoterrestris ATCC 49025, A. acidiphilus NBRC 100859, and A. herbarius DSM 13609, respectively (BLAST search against nucleotide and WGS database). The BLAST search revealed no sequence with more than $80 \%$ identity to that of the analyzed samples.

\section{Morphological and physiological characterization of A. fastidiosus}

Strains f1, f2, and f3 stained Gram-positive and produced flat, creamy-white colonies. When viewed under the microscope, they appeared as rods of a length of $4.0-4.5 \mu \mathrm{m}$ and a width of $0.8-1.0 \mu \mathrm{m}$. The growth temperature range of all these strains was found to be 20 $55^{\circ} \mathrm{C}$ with optimal growth noted at $30-45^{\circ} \mathrm{C}$. All three strains of $A$. fastidiosus grew in the $\mathrm{pH}$ range of $3.0-5.0$ with an optimum of 3.0-3.5. These results differ from the optimum values reported by Goto's group (Goto et al., 2007) because in their research the optimum $\mathrm{pH}$ was 4.0-4.5 and the optimum temperature was $40-45^{\circ} \mathrm{C}$.

Furthermore, the examined strains f1, f2, and f3 exhibited a common characteristic: they were able to produce guaiacol from vanillic acid at a temperature of $20^{\circ} \mathrm{C}, 25^{\circ} \mathrm{C}$, and $45^{\circ} \mathrm{C}$ and at an optimal pH of $3.0-3.5$. Another important biochemical feature of these strains was the lack of acid formation from erythritol. This was evidenced by the absence of a color change of the medium containing erythritol and bromophenol blue. However, all the isolated strains of $A$. acidoterrestris were able to use erythritol as a carbon source for the formation of acids. The phenotypic characteristics of the isolated $A$. fastidiosus strains and their comparison with the characteristics reported by Goto and coworkers (Goto et al., 2007) are shown in Table 2.

The classification of strains $\mathrm{f} 1, \mathrm{f} 2$, and $\mathrm{f} 3$ as $A$. fastidiosus was strongly supported by DNA sequencing analy-

Table 2. Phenotypic characteristic of $A$. fastidiosus strains f1, f2, f3 and A. fastidiosus described by Goto and others = A. fastidiosus DSM 17978 (Goto et al., 2007).

\begin{tabular}{|c|c|c|c|c|}
\hline \multirow{2}{*}{ Characteristic } & \multicolumn{3}{|c|}{ A. fastidiosus strains } & \multirow{2}{*}{$\begin{array}{l}\text { A. fastidiosus described by Goto and } \\
\text { others (Goto et al., 2007) = } \\
\text { A. fastidiosus DSM 17978 }\end{array}$} \\
\hline & $\mathrm{f1}$ & $\mathrm{f} 2$ & f3 & \\
\hline $\begin{array}{l}\text { Growth temperature }\left({ }^{\circ} \mathrm{C}\right) \\
\text { range } \\
\text { optimum }\end{array}$ & $\begin{array}{l}20-55^{\circ} \mathrm{C} \\
30-45^{\circ} \mathrm{C}\end{array}$ & $\begin{array}{l}20-55^{\circ} \mathrm{C} \\
30-45^{\circ} \mathrm{C}\end{array}$ & $\begin{array}{l}20-55^{\circ} \mathrm{C} \\
30-45^{\circ} \mathrm{C}\end{array}$ & $\begin{array}{l}20-55^{\circ} \mathrm{C} \\
40-45^{\circ} \mathrm{C}\end{array}$ \\
\hline $\begin{array}{l}\text { Growth pH } \\
\text { range } \\
\text { optimum }\end{array}$ & $\begin{array}{l}3.0-5.0 \\
3.0-3.5\end{array}$ & $\begin{array}{l}3.0-5.0 \\
3.0-3.5\end{array}$ & $\begin{array}{l}3.0-5.0 \\
3.0-3.5\end{array}$ & $\begin{array}{l}2.5-5.0 \\
4.0-4.5\end{array}$ \\
\hline Guaiacol production & + & + & + & - \\
\hline \multicolumn{5}{|l|}{ Acid production from: } \\
\hline Glycerol & - & - & - & - \\
\hline Erythritol & - & - & - & - \\
\hline D-Arabinose & - & - & - & + \\
\hline L-Arabinose & + & + & + & + \\
\hline D-Ribose & + & + & + & $n$ \\
\hline D-Xylose & + & + & + & + \\
\hline
\end{tabular}




\begin{tabular}{|c|c|c|c|c|}
\hline L-Xylose & - & - & - & - \\
\hline D-Adonitol & - & - & - & $n$ \\
\hline Methyl- $\beta$-D-xylopyranoside & - & - & - & + \\
\hline D-Galactose & + & + & + & + \\
\hline D-Glucose & + & + & + & $\mathrm{n}$ \\
\hline D-Fructose & + & + & + & $\mathrm{n}$ \\
\hline D-Mannose & - & - & + & $\mathrm{n}$ \\
\hline L-Sorbose & - & - & - & - \\
\hline L-Rhamnose & - & w & + & + \\
\hline Dulcitol & - & - & - & $\mathrm{n}$ \\
\hline Inositol & - & - & - & + \\
\hline D-Mannitol & + & + & + & + \\
\hline D-Sorbitol & - & - & - & - \\
\hline Methyl-a-D-mannopyranoside & - & - & - & - \\
\hline Methyl-a-D-glucopyranoside & - & - & - & - \\
\hline $\mathrm{N}$-Acetylglucosamine & - & - & - & $\mathrm{n}$ \\
\hline Amygdalin & - & - & - & - \\
\hline Arbutin & - & - & - & - \\
\hline Esculin ferric citrate & + & + & + & $n$ \\
\hline Salicin & $w$ & $w$ & - & - \\
\hline D-Cellobiose & + & + & + & - \\
\hline D-Maltose & w & + & + & - \\
\hline D-Lactose (bovine origin) & - & - & - & - \\
\hline D-Melibiose & - & - & - & + \\
\hline D-Saccharose (sucrose) & + & + & + & - \\
\hline D-Trehalose & + & + & + & + \\
\hline Inulin & - & - & - & - \\
\hline D-Melezitose & - & - & - & - \\
\hline D-Raffinose & - & - & - & + \\
\hline Amidon (starch) & - & - & - & - \\
\hline Glycogen & - & - & - & - \\
\hline Xylitol & - & - & - & - \\
\hline Gentiobiose & - & - & - & - \\
\hline D-Turanose & - & - & - & - \\
\hline D-Lyxose & - & - & - & + \\
\hline D-Tagatose & - & - & - & + \\
\hline D-Fucose & - & - & - & + \\
\hline L-Fucose & - & - & - & + \\
\hline D-Arabitol & - & - & - & - \\
\hline L-Arabitol & - & - & - & $\mathrm{n}$ \\
\hline Potassium gluconate & - & - & - & $n$ \\
\hline Potassium 2-ketogluconate & - & - & - & $\mathrm{n}$ \\
\hline Potassium 5-ketogluconate & + & + & + & - \\
\hline
\end{tabular}

$(+)$ positive reaction, (-) negative reaction, (w) weekly positive reaction, and (n) no information.

sis, RFLP assay, and morphological characterization. The geographical and ecological distribution is considered an important source of information on spoilage species for the beverage industry. As far as we know, this study is the first to report the isolation of $A$. fastidiosus species from
Polish pear orchard, and the second to report the isolation of these bacteria in the world. Strains f1, f2, and f3 were mostly characterized by similar morphological and biochemical properties as $A$. fastidiosus species described by Goto and others (Goto et al., 2007). According to 
these authors, $A$. fastidiosus species does not exhibit the ability to produce guaiacol. These results differ from those observed in the guaiacol production test carried out in the present study. The test showed that all the environmental strains of $A$. fastidiosus and $A$. acidoterrestris, as well as the reference strains of $A$. acidoterrestris, were able to produce guaiacol from vanillic acid at $45^{\circ} \mathrm{C}$. Unlike the other spoilage bacteria belonging to the Alicyclobacillus genus, $A$. fastidiosus was proven to produce guaiacol after $7 \mathrm{~h}$ of incubation at a temperature of $20^{\circ} \mathrm{C}$, which may pose a serious threat to the fruit juice industry. Thus far, only $A$. acidoterrestris species has been identified as capable to produce guaiacol at $21-25^{\circ} \mathrm{C}$, which is an unfavorable temperature for the growth of most thermophilic species of Alicyclobacillus (Pettipher et al., 1997, Orr et al., 2000). According to Orr and coworkers (Orr et al., 2000), guaiacol production by $A$. acidoterrestris can be noticed after 8 days of incubation in juice at $21^{\circ} \mathrm{C}$. By contrast, Sokołowska's group (Sokołowska et al., 2013) reported that $A$. acidoterrestris strains were able to produce guaiacol only after 34 days of incubation in juice at a temperature of $25^{\circ} \mathrm{C}$. The species $A$. fastidiosus is closely related to $A$. acidoterrestris, which is also a guaiacol-producing bacterium, most commonly isolated from fruit raw materials and fruit products. In conclusion, we suggest that $A$. fastidiosus should be added to the group of spoilage species.

\section{Conflicts of Interest}

The authors declare no conflict of interest.

\section{REFERENCES}

Albuquerque L, Rainey FA, Chung AP, Sunna A, Nobre MF, Grote R, Antranikian G, da Costa MS (2000) Alicyclobacillus besperidum sp. nov. and a related genomic species from solfataric soils of São Miguel in the Azores. Int. J. Syst. Evol. Microbiol. 50: 451-457. https://doi. org/10.1099/00207713-50-2-451

Baumgart J (2003) Media for the detection and enumeration of Alicyclobacillus acidoterrestris and Alicylobacillus acidocaldarius in foods. In Handbook of culture media for food microbiology. Progress in industrial microbiology. Corry JEL, Curtis GDW, Baird RM eds, pp 161-166. Elsevier

Chang S, Kang H (2004) Aligyclobacillus spp. in the fruit juice industry: history, characteristics, and current isolation/detection procedures. Crit. Rev. Microbiol. 30: 55-74. https://doi, org/10.1080/10408410490435089

Ciuffreda E, Bevilacqua A, Sinigaglia M, Corbo R (2015) Alicyclobacillus spp.: New Insights on Ecology and Preserving Food Quality through New. Approaches. Microorganisms 3: 625-640. https://doi. $\mathrm{org} / 10.3390 /$ microorganisms 3040625

Deinhard G, Blanz P, Poralla K, Altan E (1987a) Bacillus acidoterrestris sp. nov., a new thermotolerant acidophile isolated from different soils. Syst. Appl. Microbiol. 10: 47-53

Deinhard G, Saar J, Krischke W, Poralla K (1987b) Bacillus cycloheptanicus sp. nov., a new thermoacidophile containing $\omega$-cycloheptane fatty acids. Syst. Appl. Microbiol. 10: 68-73

Dekowska A, Sokołowska B, Niezgoda J (2018) Genetic heterogeneity of Alicyclobacillus strains revealed by RFLP analysis of $v d c$ region and rpoB gene. BioMed Res. Int. 5: 1-12. https://doi. org $/ 10.1155 / 2018 / 9608756$

Durak MZ, Churey JJ, Danyluk MD, Worobo RW (2010) Identification and haplotype distribution of Alicyclobacillus spp. from different juices and beverages, Int. J. Food Microbiol. 142: 286-291. https:// doi. $\mathrm{org} / 10.1016 /$ j.ijfoodmicro.2010.07.003

Goto K (2007) Parameters for detection of Alicyclobacillus and test methods. In Alicyclobacillus Thermophilic Acidophilic Bacilli. Yokota A, Fujii T, Goto K eds, pp 49-77. Springer

Goto K, Matsubara H, Mochida K, Matsumura T, Hara Y, Niwa M, Yamasato K (2002) Alicyclobacillus herbarius sp. nov., a novel bacterium containing $\omega$-cycloheptane fatty acids, isolated from herbal tea. Int. J. Syst. Evol. Microbiol. 52: 109-113. https://doi. org/10.1099/00207713-52-1-109

Goto K, Mochida K, Asahara M, Suzuki M, Kasai H, Yokota A (2003) Alicyclobacillus pomorum sp. nov., a novel thermo-acidophilic, endospore-forming bacterium that does not possess $v$-alicyclic fatty acids, and emended description of the genus Alicyclobacillus. Int. J. Syst. Evol. Microbiol. 53: 1537-1544. https://doi.org/10.1099/ ijs.0.02546-0
Goto K, Mochida K, Kato Y, Asahara M, Fujita R, An SY, Kasai H, Yokota A (2007) Proposal of six species of moderately thermophilic, acidophilic, endospore-forming bacteria: Alicyclobacillus contaminans sp. nov., Alicyclobacillus fastidiosus sp. nov., Alicyclobacillus kakegawensis sp. nov., Alicyclobacillus macrosporangiidus sp. nov., Alicyclobacillus sacchari sp. nov. and Alicyclobacillus shizuokensis sp. nov. Int. J. Syst. Evol. Microbiol. 57: 1276-1285. https://doi.org/10.1099/ijs.0.64692-0

Goto K, Nishibori A, Wasada Y, Furuhata K, Fukuyama M, Hara M (2008) Identification of thermo-acidophilic bacteria isolated from the soil of several Japanese fruit orchards. Lett. Appl. Microbiol. 46: 289-294. https://doi.org/10.1111/i.1472-765X.2007.02307.x

Groenewald H, Gouws A, Witthuhn C (2008) Isolation and identification of species of Alicyclobacillus from orchard soil in the Western Cape, South Africa. Extremophiles 12: 159-163. https://doi. $\operatorname{org} / 10.1007 / \mathrm{s} 00792-007-0112-\mathrm{z}$

IFU Method No $12(2004 / 2007)$ International Federation of Fruit Juice Producers (IFU). Method on the Detection of Alicyclobacillus in Fruit Juices. IFU Paris

Kannenberg E, Blume A, Poralla AK (1984) Properties of $\omega$-cyclohexane fatty acids in membranes. FEBS 172: 331-334

Karavaiko GI, Bogdanova TI, Tourova TP, Kondrat'eva TF, Tsaplina IA, Egorova MA, Krasil'nikova EN, Zakharchuk LM (2005) Reclassification of 'Sulfobacillus thermosulfidooxidans subsp. thermotolerans' strain K1 as Alicyclobacillus tolerans sp. nov. and Sulfobacillus disulfidooxidans Dufresne et. al 1996 as Alicyclobacillus disulfidooxidans comb. nov., and emended description of the genus Alicyclobacillus. Int. J. Sys. Evol. Microbiol. 55: 941-947. https://doi.org/10.1099/ijs.0.63300-0

Matsubara K (2003) A method for detecting and/or identifying guaiacol producing microorganism. Patent no. JP2003000259 A

Matsubara H, Goto K, Matsumura T, Mochida K, Iwaki M, Niwa M, Yamasoto K (2002) Alicyclobacillus acidiphilus sp. nov., a novel thermo-acidophilic, omega-alicyclic fatty acid-containing bacterium isolated from acidic beverages. Int. J. Syst. Evol. Microbiol. 50: 451-457. https://doi.org/10.1099/00207713-52-5-1681

Nakano Ch, Takahashi N, Tanaka N, Okada S (2015) Alicyclobacillus danci sp. nov., a slightly thermophilic, acidophilic bacterium isolated from a spoiled mixed vegetable and fruit juice product., Int. J. Syst. Evol. Microbiol. 65: 716-722. https:// doi.org/10.1099/ijs.0.068957-0

Niwa M, Kuriyama A (2013) A. acidoterrestris rapid detection kit. Fruit Process. 13: 328-331

Orr RV, Shewfelt RL, Huang CJ, Tefera S, Beuchat LR (2000) Detection of guaiacol produced by Alicyclobacillus acidoterrestris in apple juice by sensory and chromatographic analyses, and comparison with spore and vegetative cell populations. J. Food Protect. 11: 15171522

Osopale BA, Witthuhn CR, Albertyn J, Oguntoyinbo FA (2016) Culture dependent and independent genomic identification of Alicyclobacillus species in contaminated commercial fruit juices. Food Microbiol. 56:21-28. http://dx.doi.org/10.1016/i.fm.2015.11.014

Pettipher GL, Osmundson ME, Murphy JM (1997) Methods for the detection and enumeration of Alicyclobacillus acidoterrestris and investigation of growth and production of taint in fruit juice and fruit juice-containing drinks. Lett. Appl. Microbiol. 24: 185-189

Shemesh M, Pasvolsky R, Sela N, Green SJ, Zakin V (2013) Draft genome sequence of Alicyclobacillus acidoterrestris strain ATCC 49025, Genome Announcement 1(5): Article ID e00638-13. https://doi. $\mathrm{org} / 10.1128 /$ genomea.00638-13

Sokołowska B, Niezgoda J, Dekowska A, Porębska I, Nasiłowska J, Waldon-Wiewióra E, Kowalska M (2016) Incidence of Alicyclobacillus spp. in polish apple and dark berry juice concentrates and the ability of isolated $A$. acidoterrestris strains to spoilage of these juices. Post. Nauki Tecbnol. Przem. Rol.-Spo: 71: 5-20 (in Polish)

Sokołowska B, Połaska M, Dekowska A (2020) Alicyclobacillus - still current issues in the beverage industry In Safety Issues in Beverage Production. Grumezescu AM, Holban AM, eds, pp 105-146. Elsevier (Woodhead Publishing)

Sokołowska B, Skapska S, Sionek B, Niezgoda J, Chotkiewicz M (2013) Alicyclobacillus acidoterrestris - growth and production of odour compounds in apple juice Post. Nauki Technol. Przem. Rol.Spo\% 68: 19-37 (in Polish)

Uchino F, Doi S (1967) Acido-thermophilic bacteria from thermal waters. J. Agric. Biol. Chem. 31: 817-822

Wang Y, Yue T, Yuan Y, Gao Z (2010) Isolation and identification of thermo-acidophilic bacteria from orchards in China. J. Food Protect. 73: 390-394

Wang Z, Yue T, Yuan Y, Zhang Y, Gao Z, Cai R (2021) Targeting the vanillic acid decarboxylase gene for Alicyclobacillus acidoterrestris quantification and guaiacol assessment in apple juices using real time PCR. Int. J. Food Microbiol. 338: 109006

Wisotzkey JD, Jurtshuk P, Fox GE, Deinhart G, Poralla K (1992) Comparative sequence analyses on the 16S rRNA (rRNA) of Bacillus acidocaldarius, Bacillus acidoterrestris, and Bacillus cycloheptanicus and proposal for creation of a new genus, Alicyclobacillus gen. nov. Int. J. Syst. Bacteriol. 42: 263-269. 